\title{
ANALISIS SEMIOTIKA KRITIK SOSIAL MASYARAKAT MODERN DALAM VIDEO KLIP “ANTI SOCIAL” OLEH WHILE SHE SLEEPS
}

\author{
Alvin Tito Anggoro ${ }^{1} \&$ Fitria Widiyani Roosinda ${ }^{2}$ \\ 1,2 Program Studi Ilmu Komunikasi, Universitas Bhayangkara Surabaya \\ Email : nivlaotit@yahoo.co.id
}

\begin{abstract}
Music is used as a medium to convey social, political aspirations, and even becomes one of propaganda media (information / opinions) to launch an ideological movement (ideas / ideas). Song lyrics are one of the verbal communication media that have meaning in them. Research on the video clips and song lyrics of the band while she sleeps "Anti Social" is a study that aims to describe the picture of society in the modern era in the song's lyrics and to explain the meaning of social criticism illustrated. The paradigm used in this study is a critical paradigm. This research method is a qualitative method in which the data are interpreted (views) through the analysis of meaning in the form of written and oral words that are observed. The analysis used in this study is a semiotic analysis by Roland Barthes. Based on research on the video clips of Anti Social, there is a conclusion that people in the modern era have begun to lose their caring for others as evidenced in the pictures and video clips when there are people who are in trouble they just record do not want to help at all.
\end{abstract}

Keywords: Semiotic Analysis, Roland Barthes, Social Criticism, Video Clips While She Sleeps

Abtrak : Musik digunakan sebagai media untuk menyampaikan aspirasi sosial, politik, bahkan menjadi salah satu media propaganda (penerangan/ pendapat) untuk melancarkan sebuah gerakan ideologis (ide/ gagasan). Lirik lagu merupakan salah satu medial komunikasi verbal yang memiliki makna didalamnya. Penelitian terhadap video klip 1dan1 lirik lagu grup1 band 1While she sleeps "Anti Social" merupakan 1sebuah 1penelitian1 yang bertujuan untuk mendeskripsikan gambaran tentang masyarakat di era modern dalam lirik lagu tersebut dan untuk menjelaskan makna kritik sosial yang digambarkan. Paradigma yang digunakan dalam penelitian ini adalah paradigma kritis. Metode penelitian ini adalah metode kualitatif dimana data diinterpretasikan (pandangan) melalui analisis pemaknaan berupa kata tertulis maupun lisan yang diamati. Analisis yang dipakai dalam penelitian ini adalah analisis semiotika oleh Roland Barthes. Berdasarkan penelitian terhadap video klip Anti Social, terdapat kesimpulan bahwa masyarakat di era modern sudah mulai hilang rasa peduli pada sesama terbukti di gambar kan dan video klip pada saat ada orang yang sedang kesusahan mereka hanya merekam tidak ingin untuk menolong sama sekali.

Kata kunci: Analisis Semiotika, Roland Barthes, Kritik Sosial, Video Klip While She Sleeps

\section{PENDAHULUAN}

Musik merupakan salah satu media pelepasan bagi setiap kalangan penikmatnya. Nada, irama dan lirik di rangkai menjadi satu karya yang dapat menghibur, menginspirasi bahkan mengubah pola pikir sebagian pendengarnya. Para penikmat music sering kali mengaitkan setiap apa yang ereka dengar dengan music dan lagu tertentu. Ketika mereka sulit mengungkapkan apa yang sedang di rasakan.musik di anggap sudah cukup mewakili perasaan tak terdefinisi itu.

Ditambahi lagi lagu lagu dari music saat ini telah di lengkapi dengan video atau bisa di sebut music video/video clip untuk menggambarkan makna dari lagu tersebut secara visual. Video merupakan media audio visual yang sangat menarik. karena sifatnya yang banyak menghibur khalayak oleh alur ceritanya. Video musik telah menjadi bagian penting dari musik industri. Video klip saat ini yang sudah modern 
JISIP: Jurnal Ilmu Sosial dan Ilmu Politik

ISSN. 2442-6962

Vol. 9. No. 2 (2020)

berfungsi sebagai alat pemasaran untuk memproduksi sebuah album rekaman. Video klip yang baik, dengan efek spesial, gaya menarik, set menakjubkan bisa membuat seorang musisi dan karyanya tak terlupakan.

Para musisi bekerjasama dengan sutradara untuk mempresentasikan musik mereka ke dalam sebuah gambar bergerak. Sebelumnya sutradara akan mendengarkan terlebih dahulu lagunya kemudian membicarakan konsep atau ide apa yang ingin musisi dan pihak rekaman tampilkan. Perkembangan video musik juga semakin beragam sehingga banyak konsep-konsep video yang menarik. Mulai dari konsep sederhana berupa footage (cuplikan video singkat), penampilan musisi, memiliki alur cerita, sampai penggunaan efek-efek khusus di dalamnya yang terkadang tidak berhubungan dengan lagunya.

Di era millenial penuh dengan bermunculannya teknologi canggih penikmat musik dapat melihat video musik lewat internet dengan mudah dan lebih efisien, kapan dan1 di mana saja. Mulai dari1 media sosial seperti Instagram, Facebook, Twitter dan YouTube, yang menjadi situs khusus video. Pamor televisi1 disaingi oleh1 YouTube yang telah banyak diakses oleh berbagai kalangan khususnya kalangan muda yang menjadi konsumen berpengaruh dalam industri musik dan perfilman, terutama musik.dalam survei yang dilakukan Ypulse.com kepada 1.000 konsumen usia 13-32 tahun, hamper 76 persen mengatakan bahwa mereka mendengarkan musik beberapa kali sehari, 80 persen dari mereka mengatakan musik adalah bagian penting dalam hidup mereka, sementara 70 persen dari mereka mengatakan tidak bisa berhenti mendengarkan musik selama satu minggu.

Survei tersebut menunjukkan bahwa kalangan muda menjadi sasaran yang tepat untuk menawarkan dan menjual musik. Musik bertransformasi lebih komersil dalam perputaran industrinya saat ini.Video klip telah menjadi bagian tak terpisahkan dalam sebuah karya musisi dan sutradara. Selain menjadi bagian dari promosi lagu atau album, video musik juga merupakan cabang seni yang memiliki elemen-elemen artistik yang sangat kuat dan berkarakter. Dengan tak terbatasnya ide dan inspirasi dari mana saja, isi dari video musik juga menjadi semakin bermacam-macam. Seperti pada video klip yang di direct oleh tom welsh \& taylor fawcett dari Grup band metalcore asal Sheffield, Inggris yaitu While She Sleeps berjudul ANTI SOCIAL yang digarap oleh Lawrence taylor, Sean long, Matthew welsh, Aaran mckenzie, Adam savage dan dirilis pada 29 0ktober 2019. Video klip ini berlatar tempat di Sebuah studio sebagai lokasi shooting.

Lagu ANTI SOCIAL sangat disukai oleh banyak penikmat musik terbukti dengan banyaknya jumlah penonton video klip ini di youtube yang sudah mencapai 3,3 juta viewers di bulan Oktober 2019 sejak di launchingnya video klip ini pada 29 0ktober 2018. Video klip anti social ini memiliki gaya visual yang sangat unik di bandingkan dengan gaya visual music video band metal lain nya karena hanya dengan cukup satu studio besar di dalam video klip anti social ini dapat memasuk kan berbagai visual yang secara tidak langsung mengkritisi gaya hidup masyarakat jaman sekarang dalam bersosialisasi. Terlihat dari scene awal yang menunjuk kan seorang laki laki yang sedang mendengarkan lagu dengan earphone di dalam bus tiba tiba ia di pukul oleh sekelompok orang di dalam bus tersebut tetapi penumpang lain seakan tidak peduli tentang hal itu tetapi malah merekam dengan smartphone nya saja, dari scene tersebut secara tidak langsung video klip ini menyindir keadaan masyarakat jaman sekarang yang apatis dan egois terhadap lingkungan sekitar dan juga dari salah satu lirik nya yang berbunyi "Sick of corruption in wealth/Sick of corruption itself/Sick of division in colour, religion/When we're all the same" arti dalam bahasa Indonesia "Muak korupsi dalam kekayaan / Muak korupsi itu sendiri / Muak dengan warna, agama / Ketika kita semua sama" menunjukan sangat jelas mengkritik keras para koruptor dan masyarakat yang sering rasis saat ini.

Karena itu, untuk melihat makna visual dan lirik pada video klip While she sleeps tersebut dilakukan dengan pendekatan semiotika Roland Barthes. Semiotika Roland Bartes melakukan pendekatan yang secara 
JISIP: Jurnal Ilmu Sosial dan Ilmu Politik

ISSN. 2442-6962

Vol. 9. No. 2 (2020)

khusus tertuju pada bentuk tuturan yang disebut mitos. Bahasa dapat menjadi mitos dalam kondisi tertentu yang dicirikan dengan hadirnya tataran signifikasi. Tataran tersebut disebut sebagai semiologi tingkat kedua. Ada dua tingkat pertandaan menurut Barthes yang disebut denotasi dan konotasi. Denotasi merupakan tingkat pertandaan tentang petanda dan penanda atau hubungan tanda pada realitas. Makna yang dihasilkannya berupa makna eksplisit dan pasti. Pertandaan ini adalah tingkat paling konvensional yang makna pada elemen pada tanda cenderung disepakati secara sosial.

Sedangkan konotasi merupakan tingkat pertandaan, dimana dijelaskan hubungan atara penanda dan petanda dan beroperasi makna yang tidak langsung, eksplisit, dan tidak pasti, dimana segala kemungkinan tafsiran bisa terjadi. Konotasi menghadirkan makna lapis kedua, ketika pananda dikaitkan dengan berbagai aspek seperti emosi, keyakinan, dan psikologis dan dinamakan makan konotatif.Menurut Barthes terdapat makna yang berkaitan dengan mitos, lebih konvensional lebih dalam tingkatannya. Menurut pemahaman semiotika Barthes, mitos merupakan pengkodean makna dan nilai-nilai sosai menjadi hal yang dianggap alamiah. Pada tanda lapis kedua inilah mitos beroperasi, dimana maknanya bersifat konvensional secara luas oleh suatu kelompok masyarakat. Sesuatu yang arbiter dialamiahkan oleh mitos dan mematok makna yang sebenarnya bebas menjadi makna yang pasti dan memiliki patokan.Semiotika komunikasi mengkaji tanda dalam konteks komunikasi yang lebih luas, yang didalamnya terdapat berbagai elemen komunikasi, seperti media, pesan, kode, bahkan noise.Dibandingkan sistem tanda, semiotika komunikasi lebih menekankan aspek produksi tanda dalam berbagai rantai komunikasi. Di dalam semiotika komunikasi, penyampaian pesan depengaruhi pentingnya peran tanda dalam rantai komunikasi..

Manusia hidup dengan simbol-simbol, dan simbol tersebut sudah ada dan diproduksi manusia sejak manusia primitif hingga manusia modern saat ini, hanya saja bentuk dan kepentingannya yang berubah. Manusia modern sebetulnya masih mempertahankan kapasitas pembentukan simbol yang dahulu menemukan salurannya dalam kepercayaan dan ritual-ritual primitif. Dalam berbagai cara, tak disadari, manusia bergantung pada pesan pesan yang dibawa oleh simbol-simbol, baik sikap maupun perilaku yang dipengaruhi olehnya.

\section{METODE PENELITIAN}

Dalam peneltian ini, peneliti menggunakan metode analisa semiotika. Analisa semiotika merupakan suatu teknik analisa yang menarik sebuah tanda dan cara tanda-tanda tersebut bekerja. Semiotik berusaha menggali hakikat system tanda yang ke luar kaidah tata bahasa yang rumit, tersembunyi dan bergantung pada kebudayaan. Hal ini kemudian menimbulkan perhatian pada makna tambahan (connotative) dan arti penunjukan (denotative) kaitan dan kesan yang ditimbulkan dan diungkapkan melalui penggunaan dan kombinasi tanda. Pelaksanaan hal itu dilakukan dengan mengakui adanya mitos, yang telah ada dan sekumpulan gagasan yang bernilai yang berasal dari kebudayaan dan disampaikan melalui komunikasi (Sobur, 2015: 127).

Metode semiotik yang digunakan dalam penelitian ini adalah metode semiotic dengan model milik Roland Barthes. Roland Barthes, membuat sebuah model sistematis dalam menganalisis makna dari tandatanda. Focus perhatian Barthes lebih tertuju kepada gagasan tentang signifikansi dua tahap (Fiske, 1990 dalam Sobur, 2015).

\section{HASIL DAN PEMBAHASAN}

While She Sleeps telah menjadi salah satu nama yang lebih konsisten di kancah music metal Inggris selama sebagian besar dekade ini, terutama karena kekuatan semata dari ' The North Stands For Nothing ' dan 
JISIP: Jurnal Ilmu Sosial dan Ilmu Politik

ISSN. 2442-6962

Vol. 9. No. 2 (2020)

' This Is The Six ' . Rekaman terakhir grup, ' You Are We ' yang sangat biasa-biasa saja, melihat While She Sleeps melompat lebih jauh ke kereta musik metalcore politik dalam proses mengatakan banyak hal, tanpa mengatakan sesuatu yang berarti atau baru. Orang-orang ini selalu berurusan dengan unsur sosial dalam musik mereka, tetapi pada rekaman khusus itu, semuanya terasa agak dangkal dan digeneralisasi. Ternyata, ada banyak hal di sini dengan single baru mereka, ' Anti-Sosial '.

Scene 1 memiliki sebuah pesan bahwa kita sekarang hidup di masyarakat modern yang kecanduan akan informasi tetapi hilang kepedulian antar sesama. terlihat pada scene tersebut orang yang di keroyok hanya di lihat dan di rekam mereka tidak di tolong maupun dibantu. Scene 2 semakin kehidupan keluarga modern mereka tidak memperhatikan apa yang mereka konsumsi karena semakin idak diperhatikan nya kualitas makanan untuk keluarga nya. Scene 3 memperlihatkan bahwa anak-anak usia dini kurang perhatiannya dengan orang tua hingga membuat kecanduan nya dengan teknologi seperti smartphone hingga mengesampingkan pembelajaran di sekolah.Mereka lebih mementingkan social media.

Scene 4 dari scene ini video klip tersebut menyindir parah nya tingkat pencemaran laut di era masyarakat modern mereka tidak peduli dengan sampah yang di buang ke laut dapat merusak ekosistem yang ada di perairan tersebut. Scene 5 di era semakin maju nya teknologi media massa semua orang semakin mudah dalam mengakses informasi.Televisi adalah salah satu media massa yang sangat mudah di akses masyarakat modern. Tetapi mempnyai efek buruk juga masyarakat semakin enggan dan tidak peduli dengan apa yang terjadi di dunia luar secara langsung mereka hanya ingin melihat nya melalui televise. Scene 6 di era masyarakat modern seperti sekarang budaya politk kotor semakin merajalela karena banyak sekali yang mereka janji kan ke masyarakat dan tidak terpenuhi. Juga gaya hidup para politikus yang sering berfoya foya dengan uang hasil korupsi yang jumlah yang banyak.

Penelitian ini merupakan penelitian mengenai penggambaran kritik sosial terhadap kehidupan masyarakat modern dalam video klip "Anti Social". Setelah mendeskripsikan dan menganalisis hasil temuan data yang telah dikemukakan pada bab sebelumnya yang telah dilakukan oleh penulis, maka pada bab ini dapat disimpulkan bahwa :

Makna Denotasi dari kritik sosial terhadap kehidupan masyarakat modern dalam video musik "Anti Sosial" adalah Tampak sebuah pengeroyokan yang terjadi di dalam bis, Kondisi kelas sedang melakukan belajar dan mengajar yang di lakukan oleh seorang guru. Sedangkan para siswa sibuk bermain smartphone, Antrian pembeli di apotik yang mengasih resep dokter tetapi di berikan oleh petugas apotik sekantong makanan fastfood, Terlihat seorang anak kecil perempuan yang sedang melihat akuarium yang penuh dengan sampah plastik dengan wajah terlihat murung,tiga orang yang sedang duduk santai di rumah sambil menonton televisi.tidak peduli dengan di luar bahwa sedang terjadi kericuhan, seorang pria ber jas yang sedang berpidato dan juga berfoya-foya dengan minuman keras.

Makna Konotasi dari kritik sosial terhadap kehidupan masyarakat modern dalam video musik "Anti Sosial" adalah masyarakat modern mulai ketergantungan dengan Smartphone dan tidak peduli dengan keadaan sekitar mereka tidak mau menolong hanya mengutamakan ingin merekam demi konten social media, kondisi anak di jaman sekarang yang sudah mengesampingkan kegiatan belajar. Karena pada jaman sekarang para anak-anak kecil sudah memakai smartphone mereka sibuk dengan social media, masyarakat modern sekarang terlihat ketergantungan akan sesuatu yang instan dan mempunyai efek buruk bagi tubuh,

Efek dari masyarakat modern tidak peduli akan lingkungan yang suka buang sampah sembarangan membuat ekosistem perairan tercemar penuh dengan sampah yang sulit terurai, masyarakat modern yang 
JISIP: Jurnal Ilmu Sosial dan Ilmu Politik

ISSN. 2442-6962

Vol. 9. No. 2 (2020)

seakan akan tidak peduli dengan dunia luar walaupun kejadian itu dekat dengan mereka.Masyarakat modern hanya melihat nya dari televisi tidak peduli akan kejadian tersebut terlihat dari seorang yang mengganti televisi nya seakan tidak tertarik dengan kejadian itu, para politikus yang hanya sekedar obral janji dan kurang jujur terhadap masyarakat luas.

Makna Mitos dari kritik sosial terhadap kehidupan masyarakat modern dalam video musik "Anti Sosial" adalah Smartphone dapat membuat orang menjadi individualis dan apatis, Kurang nya perhatian dan pengawasan orangtua membuat anak-anak kecanduan smartphone, Masyarakat semakin tidak memperhatikan kesehatan nya, Ketidak pedulian masyarakat modern akan pencemaran perairan mempunyai efek buruk bagi kesehatan untuk jangka panjang,Semakin modern teknologi informasi semakin berkembang masyarakat modern sangat mudah mengakses informasi, Semakin tinggi kedudukan atau jabatan di masyarakat semakin besar juga cobaan dan godaan yang di dapatkan.

\section{KESIMPULAN}

Peneitian ini menggunakan analisis Semiotika Rolland Barthes, pada musik video "Holy War"oleh grup band While She Sleeps, yang mengangkat sebuah isu social yang ada di kehidupan masyarakat modern saat ini sebagai tema utama dalam video musiknya. Ada beberapa saran yang ingin penulis sampaikan dalam video musik "Anti Social" yaitu, dalam video musik "Anti Social" sebaiknya menyisipkan sebuah subtitle lirik dalam video musiknya. Karena video musik ini merupakan genre metal, menggunakan sebuah vocal suara yang tidak biasa. Sehingga penonton awam yang tidak terbiasa dengan musik metal akan sulit mendengar lirik yang dinyanyikan dalam video musik ini.

Memperbanyak konten musik / video musik yang menyuarakan tentang isuisu sosial di masyarakat, seperti tema dalam Musik dan Video musik "Anti Social". Agar bisa mewakilkan suara dairi sekian banyak orang. Peneliti di sini berharap untuk penelitian selanjutnya dapat dilakukan analisis video musik metal dengan tema lainnya, agar mengetahui ide-ide dan kritik apa saja yang berusaha disampaikan dalam musik metal.

\section{Daftar Pustaka}

Gumilang, P. (2017). Analisis Semiotika Komik Sebagai Media Kritik Sosial (Studi Pada Komik "Mice” di Harian Kompas Periode 21 Juni Sampai Dengan 16 Agustus 2015). Universitas Lampung.

Haryanto, A. (2016). Memahami Selera Musik Milenial. https://tirto.id/memahami-selera-musik-milenialb49a

Lebang, Y. A. P. (2015). Analisis Semiotika Simbol Kekuasaan Pada Rumah Adat Toraja (Tongkonan Layuk). E-Journal Ilmu Komunikasi, 3(4), 158-172.

Sobur, A. (2015). Analisis Teks Media. Remaja Rosdakarya Offset.

Vera, N. (2015). Semiotika dalam riset komunikasi. Ghalia Indonesia. 